\title{
PON1 wt Allele
}

National Cancer Institute

\section{Source}

National Cancer Institute. PON1 wt Allele. NCI Thesaurus. Code C116048.

Human PON1 wild-type allele is located in the vicinity of 7q21.3 and is approximately 99 $\mathrm{kb}$ in length. This allele, which encodes serum paraoxonase/arylesterase 1 protein, is involved in detoxification of lactones, aromatic carboxylic acid esters and organophosphates. Genetic variation is associated with microvascular complications of diabetes 5, and increased susceptibility to coronary artery disease, coronary artery spasm 2, and organophosphate poisoning. 